\title{
ANALISIS IMPLEMENTASI PRINSIP-PRINSIP GOOD CORPORATE GOVERNANCE (GCG) TERHADAP PERSEPSI MASYARAKAT DAN KINERJA KEUANGAN PADA PERUSAHAAN DAERAH AIR MINUM (PDAM) KOTA PALOPO
}

\author{
Burhan Rifuddin ${ }^{1}$ \\ Afdal Kurniawan Jamaluddin ${ }^{2}$ \\ burhanrifuddin@gmail.com
}

\begin{abstract}
The main problem of this research is how is the implementation of the principles of Good Corporate Governance (GCG) on public perceptions and financial performance in the Regional Drinking Water Company (PDAM) of Palopo City? The sub-main problems are: 1 . How is the implementation of GCG principles in PDAM Palopo City? 2. What is the community's perception of PDAM Palopo City? 3. How is the financial performance in PDAM Kota Palopo? 4. How is the relationship between the implementation of GCG principles on financial performance in PDAM Kota Palopo. This research aims: a. To find out the implementation of GCG principles in PDAM Palopo City, b. To find out people's perceptions of PDAM Palopo City, c. To determine the financial performance of PDAM Palopo City, d. To find out the relationship between the implementation of GCG principles on financial performance in PDAM Palopo City. Sources of data used in this study are primary data obtained directly from the object of research as a source of information sought in this case from the Palopo City PDAM office and secondary data through library research related to the research title and data collection through interviews., observation, documentation, triangulation, questionnaire. The approach used is a case study approach. Balanced qualitative and quantitative mixed data analysis (Concurrent Trianggulation). The results showed that: 1) The implementation of GCG principles in 2010-2012 (pre) in PDAM went well with a percentage of $49.74 \%$ and after the implementation of GCG in 2012-2014, the application was very good with a percentage of $53.57 \%$. 2) The public perception of PDAM Palopo City is classified as good with a percentage of $50.27 \%$. 3) Financial performance in PDAM Kota Palopo is classified as poor by obtaining a value from the financial aspect of 45 , due to the annual decline in profitability indicators such as NPM, ROA and ROE.

4) The implementation of GCG does not have a strong relationship with financial performance because the low positive relationship from pre and post implementation of GCG in PDAM only strengthens in the administration section, while the financial performance is not in line.
\end{abstract}

Keywords: Good Corporate Governance, Public Perception, Financial Performance. 


\begin{abstract}
Permasalahan pokok penelitian ini adalah bagaimana implementasi prinsip-prinsip Good Corporate Governance (GCG) terhadap persepsi masyarakat dan kinerja keuangan di Perusahaan Daerah Air Minum (PDAM) Kota Palopo? Adapun sub pokok masalahnya yaitu: 1. Bagaimana implementasi prinsip-prinsip GCG di PDAM Kota Palopo? 2. Bagaimana persepsi masyarakat terhadap PDAM Kota Palopo? 3. Bagaimana kinerja keuangan di PDAM Kota Palopo? 4. Bagaimana hubungan dari implemantasi prinsip-prinsip GCG terhadap kinerja keuangan di PDAM Kota Palopo. Penelitian ini bertujuan: a. Untuk mengetahui implementasi prinsip- prinsip GCG di PDAM Kota Palopo, b. Untuk mengetahui persepsi masyarakat terhadap PDAM Kota Palopo, c. Untuk mengetahui kinerja keuangan di PDAM Kota Palopo, d. Untuk mengetahui hubungan dari implementasi prinsip-prinsip GCG terhadap kinerja keuangan di PDAM Kota Palopo. Sumber data yang digunakan dalam penelitian ini adalah data primer yang diperoleh secara langsung dari objek penelitian sebagai sumber informasi yang dicari dalam hal ini berasal dari kantor PDAM Kota Palopo dan data sekunder melalui studi pustaka (library research) berkaitan dengan judul penelitian serta pengumpulan data melalui wawancara, observasi, dokumentasi, trianggulasi, kuesioner. Adapun pendekatan yang digunakan adalah pendekatan studi kasus. Analisis data campuran kualitatif dan kuatitatif secara seimbang (Concurrent Trianggulation). Hasil penelitian menunjukkan bahwa : 1) Implemtasi prinsip-prinsip GCG tahun 2010-2012 (pra) di PDAM berjalan baik dengan persentase $49,74 \%$ dan sesudah penerapan GCG di tahun 2012-2014, penerapannya sangat baik dengan persentase 53,57\%. 2) Persepsi masyarakat terhadap PDAM Kota Palopo adalah tergolong baik dengan persentase 50,27\%. 3) Kinerja keuangan di PDAM Kota Palopo tergolong kurang dengan memperoleh nilai dari aspek keuangan 45, disebabkan penurunan setiap tahunnya indikator profitabilitas seperti NPM,ROA dan ROE.

4) Penerapan GCG tidak memiliki hubungan yang kuat terhadap kinerja keuangan dikarenakan hubungan positif rendah dari pra dan pasca implementasi GCG di PDAM hanya memperkuat di bagian administrasi, sedangkan di kinerja keuangan tidak sejalan.
\end{abstract}

Kata Kunci : Good Corporate Governance, Persepsi Masyarakat, Kinerja Keuangan.

\title{
PENDAHULUAN
}

\section{A. Latar Belakang}

Pelaksanaan tata kelola perusahaan yang baik atau yang lebih dikenal dengan istilah Good Corporate Governance (GCG) menjadi isu yang mengemuka di Indonesia. Hal tersebut 
merupakan topik utama yang banyak diperbincangkan khalayak ramai dalam beberapa tahun ini, terutama sejak krisis di Indonesia tahun 1998, menjadi awal masuknya konsep Good Corporate Governance (GCG) yang diperkenalkan oleh Pemerintah Indonesia dan IMF dalam rangka pemulihan pasca krisis. Dewasa ini, tuntutan atas implementasi prinsip-prinsip GCG pada perusahaan dan lembaga usaha menjadi permasalahan yang sangat penting. Penerapan GCG juga membuat pengelolaan perusahaan menjadi lebih fokus dan lebih jelas dalam pembagian tugas, tanggung jawab, dan pengawasan. ${ }^{1}$ Sebagai salah satu aset daerah adalah Perusahaan Daerah atau di Indonesia dikenal dengan nama Badan Usaha Milik Daerah (BUMD) yang memainkan peranan penting untuk meraih pendapatan daerah. Keberadaan Badan Usaha Milik Daerah (BUMD) sebagai lembaga bisnis yang dimiliki dan dikelola oleh pemerintah daerah memiliki peran strategis dalam pembangunan daerah. Keberadaan BUMD diyakini dapat memberikan multiplier effect yang sangat besar bagi perekonomian masyarakat khususnya di daerah. Pendirian BUMD diharapkan dapat membuka lapangan kerja baru, menggerakkan sektor-sektor ekonomi produktif, serta dapat meningkatkan Pendapatan Asli Daerah (PAD). ${ }^{2}$ Layaknya sebuah perusahaaan, BUMD memiliki tugas untuk mengelola suatu bisnis yang memiliki prospek keuntungan, di mana dengan adanya keuntungan tersebut akan menjadi pemasukan bagi daerah untuk membiayai pembangunan daerahnya.

Pentingnya penerapan prinsip-prinsip Good Corporate Governance disadari berbagai pihak. Misalnya kewajiban penerapan Good corporate Governance pada Badan Usaha Milik Negara (BUMN) berdasarkan dalam Peraturan Menteri Negara BUMN Nomor PER01/MB/2011 tanggal 01 Agustus tentang penerapan Tata Kelola Perusahaan yang baik (Good Corporate Governance) pada Badan Usaha Milik Negara harus senantiasa berlandaskan pada lima prinsip dasar. Pertama, transparansi (transparency), yaitu keterbukaan dalam melaksanakan proses pengambilan keputusan dan keterbukaan dalam mengungkapkan informasi material dan relevan mengenai perusahaan. Kedua, akuntabilitas (accountability), yaitu kejelasan fungsi, pelaksanaan dan pertanggungjawaban Organ sehingga pengelolaan perusahaan terlaksana secara efektif. Ketiga, pertanggungjawaban (responbility), yaitu kesesuaian didalam pengelolaan perusahaan terhadap peraturan perundang-undangan dan prinsip-prinsip korporasi yang sehat. Keempat, kemandirian (indepedency), yaitu keadaan dimana perusahaan dikelola secara professional tanpa benturan kepentingan dan pengaruh/tekanan dari pihak manapun yang tidak sesuai dengan peraturan perundangundangan dan prinsip-prinsip korporasi yang sehat. Kelima, kewajaran (fairness), yaitu keadilan dan kesetaraan didalam memenuhi hak-hak Pemangku Kepentingan (stakeholders) yang timbul berdasarkan perjanjian dan peraturan perundang-undangan. ${ }^{3}$ Badan Usaha Milik Daerah (BUMD) merupakan salah satu bentuk badan usaha yang dimiliki oleh Pemerintah 
Daerah yang sesungguhnya memiliki karakteristik yang hampir tidak berbeda dengan BUMN, belum mempunyai regulasi pedoman penerapan prinsip-prinsip Good Corporate Governance padahal secara legal, BUMN dan BUMD sama-sama merupakan bagian dari keuangan negara (berdasarkan UU No. 17 tahun 2003 tentang Keuangan Negara), tidak dapat dipungkiri ditingkat operasional secara umum, kinerja BUMD jauh ketinggalan dibanding BUMN. Dalam upaya perbaikan dan peningkatan kualitas penerapan GCG, BUMD wajib melakukan pengukuran terhadap penerapan GCG, sehingga apabila masih terdapat kekurangan dalam pengimplementasiannya, BUMD dapat segera menetapkan rencana tindak (actionplan) yang meliputi tindakan korektif (corrective action) yang diperlukan.

Sebutan Good Corporate Governance merupakan sebutan baru baik bagi ilmu maupun agama manapun termasuk ajaran Islam yang telah muncul sebelum kehidupan modern. Meskipun istilah corporate governance masih baru, tetapi konsepnya terdapat dalam ajaran islam yaitu di dalam Al-Qur'an dan hadits, seperti yang terdapat dalam surat al-Baqarah ayat 148, Ayat ini sudah menjelaskan jauh sebelum GCG itu muncul yaitu menyerukan Manusia berlomba-lomba dalam hal kebaikan dan surat al-Baqarah ayat 282-283, tentang proses transaksi secara bertahap.

QS al-Baqarah: 148

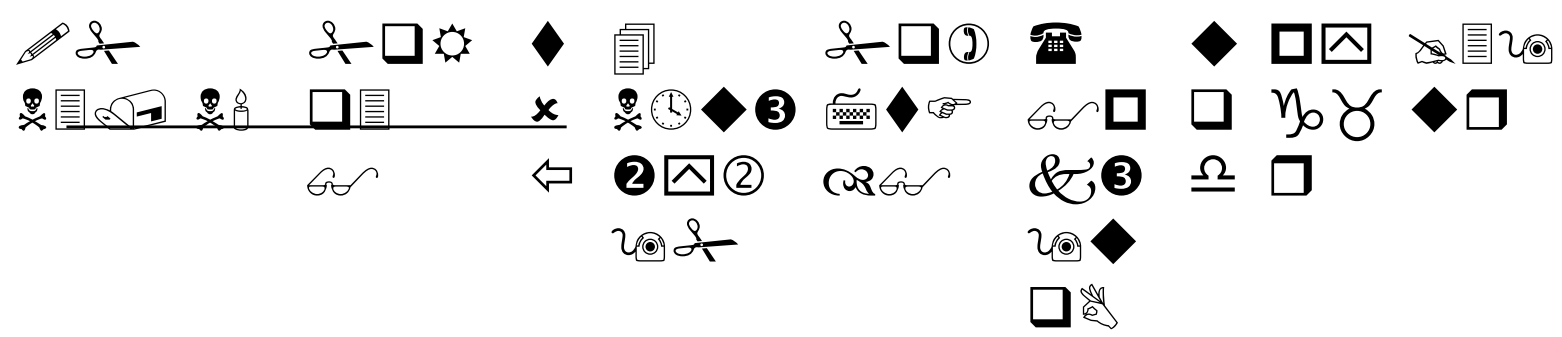




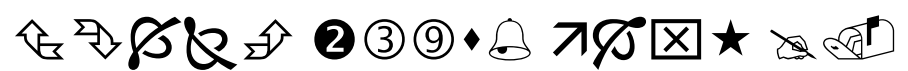 0 वा क्ष $\Omega$ (ग) or $\rightarrow$ (10) $\triangle \succ$}

Terjemahan Ayat :

“dan bagi tiap-tiap umat ada kiblatnya (sendiri) yang ia menghadap kepadanya. Maka berlomba-lombalah (dalam membuat) kebaikan. di mana saja kamu berada pasti Allah akan mengumpulkan kamu sekalian (pada hari kiamat). Sesungguhnya Allah Maha Kuasa atas segala sesuatu". ${ }^{4}$

Ayat diatas menerangkan mengenai arti pentingnya menjaga catatan secara tepat sehingga tidak ada pihak yang mendapat perlakuan ketidakadilan. Pelajaran dari ayat ini adalah dibutuhkannya tranparency dan disclosure dalam perjanjian bisnis. Pemahaman terhadap prinsip-prinsip Tata Kelola perusahaan (Corporate governance) telah dijadikan acuan dalam pencapaian kinerja perusahaan yang berkesinambungan serta tetap memperhatikan pihakpihak yang berkepentingan dan lingkungan masyarakat. Penerapan prinsip-prinsip Good Corporate Governance yang baik disuatu perusahan akan berdampak langsung pada lingkungan sekitar. Dalam penerapan Good Corporate Governance diharapkan sejalan dengan persepsi masyarakat terhadap perusahaan tersebut sehingga apa yang menjadi tujuan dan pemanfaatan dari perusahaan dapat tercapai mengingat PDAM adalah perusahaan daerah yang menjadi tujuan utama meningkatkan perekonomian dan kondisi di daerah tersebut dalam pelayanan jasa. Kinerja perusahaan yang baik, stabil dan cenderung meningkat akan senantiasa disenangi oleh para investor. Sedangkan perusahaan yang memiliki kinerja buruk, tidak stabil serta profit yang cenderung menurun tidak akan dilirik oleh investor. ${ }^{5}$ Kinerja Keuangan Perusahaan disebut juga suatu penentuan yang mengukur mengenai baik buruknya perusahaan dalam prestasi kerja dapat dilihat dari kondisi keuangannya pada periode tertentu. Kondisi keuangan dianalisis dengan alat-alat analisis keuangan. Pengukuran kinerja keuangan dalam perusahaan dilakukan untuk mengetahui apakah hasil yang dicapai telah sesuai dengan perencanaan. Dengan meningkatnya kinerja keuangan perusahaan berarti perusahaan dapat mencapai tujuan dari didirikannya perusahaan tersebut. ${ }^{6}$ Dalam mengukur kinerja keuangan perusahaan dapat menggunakan Net Profit Margin (NPM), Return On Asset (ROA) dan Return On Equity (ROE). Salah satu perusahaan yang menerapkan GCG adalah Perusahaan Daerah Air Minum (PDAM) di Kota Palopo, awal mula dari penerapan GCG di PDAM yaitu pada tahun 2012, yang melatarbelakangi adalah adanya regulasi pemerintah untuk setiap perusahaan yang berada di kota palopo untuk menerapkannya sehingga 
terciptanya Good Corporate Governance di perusahaan BUMD tersebut. ${ }^{7}$ Berdasarkan asumsi, pertimbangan dan alasan pada uraian latar belakang masalah diatas telah mendorong penulis untuk mengetahui dan mempelajari mengenai perusahaan milik daerah yang bergerak dibidang pelayanan jasa yang berkaitan dengan profitabilitas perusahaan dalam hal Good Corporate Governance sebagai pokok pembahasan penulisan skripsi ini dengan mengambil judul "Analisis implementasi prinsip-prinsip Good Corporate Governance terhadap persepsi Masyarakat dan kinerja keuangan pada Perusahaan Daerah Air Minum (PDAM) Kota Palopo".

\section{B. Rumusan \\ masalah}

Berdasasarkan latar belakang diatas, yang menjadi permasalahan adalah sebagai berikut

1. Bagaimana implementasi prinsip-prinsip Good Corporate Governance (GCG) di PDAM Kota Palopo?.

2. Bagaimana persepsi masyarakat terhadap PDAM Kota Palopo?

3. Bagaimana kinerja keuangan di PDAM Kota Palopo?

4. Bagaimana hubungan implementasi prinsip-prinsip Good Corporate Governance (GCG) terhadap kinerja keuangan di PDAM Kota Palopo?

C.

\section{Operasional}

\section{Defenisi}

Skripsi ini berjudul "Analisis implementasi prinsip-prinsip Good Corporate Governance (GCG) terhadap persepsi masyarakat dan kinerja keuangan Perusahaan Pada Perusahaan Daerah Air Minum (PDAM) Kota Palopo maka sangat penting untuk mendefenisikan operasional variabel agar tidak terjadi kesalahan penafsiran dan untuk memudahkan penelitian

1. Good Corporate Governance (GCG) merupakan suatu rangkaian proses, kebiasaan, kebijakan aturan, dan institusi yang mempengaruhi pengarahan, pengelolaan, serta pengontrolan atau korporasi yang melibatkan pemangku kepentingan, pengurus, pihak kreditur, pemerintah, karyawan serta pemegang kepentingan internal dan eksternal dengan tujuan meningkatkan kinerja keuangan, mengurangi resiko merugikan dan meningkatkan kepercayaan investor.

2. Persepsi masyarakat merupakan sebuah proses dimana sekelompok individu atau 
masyarakat yang hidup dan tinggal bersama dalam wilayah tertentu, memberikan tanggapan terhadap hal-hal yang dianggap menarik dari lingkungan tempat tinggal mereka.

3. Kinerja keuangan perusahaan merupakan pencapaian prestasi perusahaan pada suatu periode yang menggambarkan kondisi kesehatan keuangan perusahaan dengan indikator kecukupan modal, likuiditas dan profitabilitas.

4. Sedangkan ruang lingkup penelitian ini adalah bagaimana implementasi dari prinsip-prinsip Good Corporate Governance pada PDAM Kota Palopo terhadap persepsi masyarakat dan kinerja keuangan di perusahaan tersebut. Penerapan Good Corporate Governance di PDAM dimulai sejak tahun 2012, oleh karena itu dalam penelitian ini, peneliti akan melihat sebelum dan sesudah di terapkannya Good Corporate Governance di perusahaan tersebut.

\section{KAJIAN PUSTAKA}

\section{A. Badan Usaha Milik Daerah (BUMD)}

Perusahaan Daerah ialah semua perusahaan yang didirikan berdasarkan Undang-undang yang modalnya untuk seluruhnya atau untuk sebagian merupakan kekayaan Daerah yang dipisahkan, kecuali jika ditentukan lain dengan atau berdasarkan Undang-undang. ${ }^{8}$

\section{B. Pengertian dan konsep dasar Good Corporate Governance (GCG)}

Istilah Good Corporate Governance (GCG) telah banyak didefenisikan dalam berbagai macam literatur, tetapi beberapa defenisi tersebut berbeda satu sama lain, bergantung pada kecenderungan pihak yang mendefenisikan. Good Corporte Governance secara defenitif merupakan sistem yang mengatur dan mengendalikan perusahaan untuk menciptakan nilai tambah (value added) untuk semua stakeholder. Forum for Corporate Governance in

Indonesia (FCGI), mendefenisikan bahwa Corporate Governance didefenisikan sebagai seperangkat peraturan yang mengatur hubungan antara pemangku kepentingan, pengurus (pengelola) perusahaan, pihak kreditur, pemerintah, karyawan, serta para pemegang kepentingan internal dan eksternal lainnya yang berkaitan dengan hak-hak dan kewajiban mereka atau dengan kata lain suatu sistem yang mengendalikan perusahaan. ${ }^{9}$ Sedangkan Bank Dunia (World Bank) mendefenisikan Good Corporate Governance (GCG) ialah sebagai kumpulan hukum, peraturan, dan kaidah-kaidah yang wajib dipenuhi, yang dapat mendorong kinerja sumber-sumber perusahaan untuk berfungsi secara efisien guna menghasilkan nilai ekonomi jangka panjang yang berkesinambungan bagi para pemegang saham maupun masyarakat sekitar secara keseluruhan. ${ }^{10}$ Menurut KEPMEN BUMN Nomor PER01/MB/2011 tanggal 01 Agustus pada pasal 1, Good Corporate Governance adalah prinsip- 
prinsip yang mendasari suatu proses dan mekanisme pengelolaan perusahaan berlandaskan peraturan perundang-undangan dan etika berusaha. ${ }^{11}$

Implementasi prinsip-prinsip GCG menyangkut pengembangan dua aspek yang saling berkaitan satu sama lain, yaitu: perangkat keras (hardware) dan perangkat lunak (software). Hardware yang lebih bersifat teknis mencakup pembentukan atau perubahan struktur dan system organisasi. Sedangkan, software yang lebih bersifat psikososial mencakup perubahan paradigma, visi, misi, nilai (values), sikap (attitude), dan etika keperilakuan (behavioral ethics). ${ }^{12}$

\section{Sejarah Good Corporate Governance}

Sejarah corporate governance telah dimulai sejak 200 tahun yang lalu, yaitu ketika Blackstone menggambarkan corporation sebagai little republic. Dengan penganalogian seperti itu memberi konsekuensi bahwa suatu corporation harus dikelola sebagaimana suatu republik dan seringkali perusahaan disebut sebagai miniatur Negara.

\section{Prinsip-Prinsip Good Corporate Governance}

Prinsip merupakan suatu kaidah, norma ataupun pedoman korporasi yang diperlukan dalam system pengelolaan BUMN yang sehat. Berikut ini adalah prinsip-prinsip GCG yang dimaksudkan dalam Keputusan Menteri BUMN Nomor : PER-01/MBU/2011 tentang penerapan tata kelola perusahaan yang baik (Good Corporate Governance) pada Badan Usaha Milik Negara (BUMN) adalah :

1. Transparansi (transparency)

2. Akuntabilitas (accountability)

3. Pertanggungjawaban (responbility)

4. Kemandirian (indepedency)

5. Kewajaran (fairness). ${ }^{13}$

\section{E. Tujuan dan Manfaat Good Corporate Governance}

Tujuan dari penerapan Good Corporate Governance adalah menciptakan nilai tambah bagi para pemangku kepentingan. Hal ini disebabkan karena Good Corporate Governance (GCG) dapat mendorong terbentuknya pola kerja manajemen yang bersih, transparan dan professional. Implementasi Good Corporate Governance dalam pengelolaan perusahaan mencerminkan bahwa perusahaan tersebut telah dikelola dengan baik dan transparan. Manfaat penerapan implementasi Good Corporate Governance antara lain pertama, Good Corporate Governance bukan hanya membentuk system check and balance yang efektif dan mengeliminir mismanagement akan tetapi lebih dari itu akan menjamin kokohnya korporasi seiring dengan meningkatnya kinerja melalui terciptanya proses pengambilan keputusan yang lebih baik dan efisiensi. Kedua, meningkatnya nilai (value) korporasi karena perbaikan kinerja keuangan, mengurangi resiko terjadinya keputusan tidak fair, dan dikelola atas dasar 
best practice, yang pada gilirannya akan meningkatkan value. Ketiga, meningkatkan kepercayaan investor dan keempat, pemegang saham merasa puas dengan kinerja korporasi karena Good Corporate Governance meningkatkan shareloders value dan deviden. ${ }^{14}$

\section{F. Struktur Good Corporate Governance}

Umumnya terdapat 2 (dua) model struktur internal corporate governance di dunia, yaitu The Anglo-American system dan The Continental Europe system. Model Anglo-American merupakan model yang digunakan di US dan UK, dimana struktur governance terdiri dari RUPS (Rapat Umum Pemegang Saham), Board of Directors (executive directors nonexecutive directors), serta executive managers yang dipimpin oleh CEO. Model ini disebut juga single atau one-board system, karena dalam Board of Directors tidak memisahkan keanggotaan Dewan Komisaris (Board of Commissioners) dan Direksi.

\section{G. Mekanisme Good Corporate Governance}

Mekanisme corporate governance merupakan suatu aturan main, prosedur, dan hubungan yang jelas antara pihak yang mengambil keputusan dengan pihak yang melakukan kontrol/pengawasan terhadap keputusan tersebut. Mekanisme corporate governance diarahkan untuk menjamin dan mengawasi berjalannya system governance dalam sebuah organisasi. Terdapat 2 mekanisme untuk membantu menyamakan perbedaan kepentingan antara pemegang saham dan manajer dalam rangka penerapan GCG, yaitu: (1) mekanisme pengendalian perusahaan, dan (2) mekanisme pengendalian eksternal berdasarkan pasar. ${ }^{15}$

1. Dewan Komisaris

2. Dewan Direksi

3. Komisaris Independen

4. Komite Audit

\section{H. Konsepsi teoritik mengenai persepsi}

Persepsi adalah tanggapan (penerimaan) langsung dari sesuatu, serapan dan proses seseorang mengetahui beberapa hal melalui pancainderanya. ${ }^{16}$ Persepsi seseorang dapat timbul dari pengalaman yang telah diperolehnya, baik yang dilakukan sendiri maupun kesan dari orang lain. Akumulasi dari persepsi akan mampu membentuk suatu opini asumsi atau kesimpulan tentang sesuatu yang telah dialaminya. ${ }^{17}$

\section{Kinerja Keuangan Perusahaan}

Kinerja adalah sesuatu yang dicapai, prestasi yang diperlihatkan, kemampuan kerja (tentang peralatan). Keuangan adalah seluk-beluk uang, urusan uang, keadaan uang, Perusahaan adalah kegiatan (pekerjaan dan sebagainya) yang diselenggarakan dengan peralatan atau dengan cara teratur dengan tujuan mencari keuntungan (dengan menghasilkan sesuatu, mengolah atau membuat barang-barang, berdagang, memberikan jasa, dan sebagainya), organisasi berbadan hukum yg mengadakan transaksi atau usaha. ${ }^{18}$ Dapat disimpulkan menurut bahasa bahwa Kinerja keuangan perusahaan adalah sesuatu yang 
dicapai/prestasi yang diperlihatkan mengenai keadaan keuangan oleh organisasi berbadan hukum yang mengadakan transaksi atau usaha. ${ }^{19}$

\section{J. Pengukuran Kinerja Keuangan}

Untuk mengetahui baik buruknya kondisi keuangan suatu perusahaan, ada beberapa hal yang menjadi tolak ukur dalam menganalisis dan menilai kondisi keuangan perusahaan tersebut, antara lain sebagai berikut :

1. Likuiditas (Liquidity)

B. Solvabilitas (Solvability)

C. Profitabilitas/ Rentabilitas (Profitability)

\section{K. Indikator dalam Perhitungan Profitabilitas}

Rasio profitabilitas dapat diukur dengan beberapa indikator, yaitu NPM (net profit margin), ROA (return on assets), dan ROE (return on equity).

1. NPM (Net Profit Margin)

2. ROA (Return on Asset)

3. ROE (Return on Equity)

\section{Pengukuran Kinerja Keuangan PDAM}

Pengukuran kinerja keuangan PDAM sendiri berdasarkan pada Keputusan Menteri Dalam Negeri Nomor 47 tahun 1999 Tentang Pedoman Penilaian Kinerja Perusahaan Daerah Air Minum.

\section{Pengaruh Good Corporate Terhadap Kinerja Keuangan}

Kinerja keuangan suatu perusahaan ditentukan oleh sajauh mana keseriusannya menerapkan good corporate governance. Dalam majalah SWA (2001) menyebutkan bahwa terdapat sebanyak 25 perusahaan peringkat teratas yang menerapkan good corporate governance dengan baik secara tidak langsung menaikkan nilai sahamnya. Secara teoritis praktik good corporate governance dapat meningkatkan kinerja keuangan mereka, mengurangi risiko yang mungkin dilakukan oleh dewan dengan keputusan yang menguntungkan sendiri, umumnya good corporate governace dapat meningkatkan kepercayaan investor untuk menanamkan modalnya yang akan berdampak terhadap kinerjanya. $^{20}$

\section{N. Kerangka Pemikiran}

Berdasarkan latar belakang penelitian dan tinjauan pustaka, dapat diketahui bahwa GCG merupakan suatu sistem yang mengatur bagaimana organisasi dioperasikan dan dijalankan dengan baik karena GCG sebagai sarana interaksi yang mengatur antar struktur dan mekanisme yang menjamin adanya kontrol, namun tetap mendorong efisiensi dan kinerja 
perusahaan dengan berlandaskan lima prinsip GCG yaitu: Transparansi, Akuntabilitas, Pertanggungjawaban, Kemandirian, Kewajaran. Sebuah perusahaan akan mengalami peningkatan kinerja jika menerapkan GCG. Penelitian terdahulu yang menjadi acuan dalam penelitian ini mempunyai hasil yang tidak sama yang diukur dengan memakai rasio NPM, ROA, dan ROE, oleh karena itu peneliti tertarik untuk menganalisis Pra dan Pasca Implementasi GCG serta mengukur hubungan GCG terhadap Kinerja Keuangan perusahaan dengan menggunakan rasio NPM, ROA dan ROE sehingga dirumuskan kerangka pemikiran penelitian ini sebagai berikut :

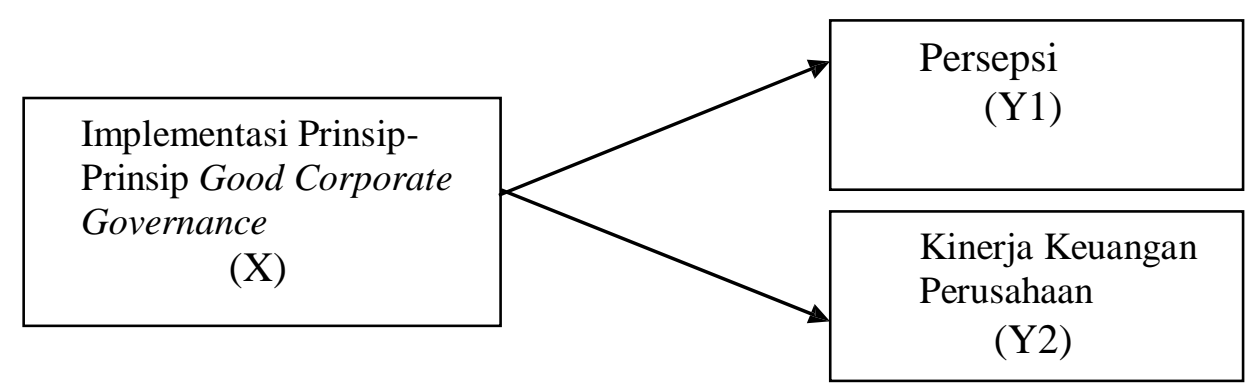

Gambar 2.3 Kerangka Pemikiran

Penelitian ini menggunakan Implementasi Prinsip-Prinsip GCG sebagai variabel independen (variabel X), persepsi masyarakat terhadap perusahaan sebagai variabel dependen (variabel Y1) dan kinerja keuangan perusahaan sebagai variabel dependen (variabel Y2) yang diukur dengan menggunakan rasio profitabilitas yaitu: NPM (net profit margin), ROA (return on asset), ROE (return on equity).

\section{METODE PENELITIAN}

\section{A. Pendekatan dan Jenis Penelitian}

Pendekatan yang digunakan dalam penelitian ini adalah pendekatan studi kasus. Sedangkan jenis penelitian ini merupakan campuran kualitatif dan kuantitatif secara seimbang (Concurrent Trianggulation).

\section{B. Lokasi Penelitian}

Penelitian ini akan dilakukan di kantor PDAM Jln. Pongsimpin-Latuppa No.22, Kota Palopo pada bulan November 2015.

\section{Populasi dan Sampel}

Penenelitian ini membahas tentang Pra dan Pasca Implementasi Prinsip-Prinsip Good Corporate Governance Terhadap Kinerja Keuangan Perusahaan dengan mengambil populasi pada Perusahaan Daerah Air Minum (PDAM) Kota Palopo. Populasi dari penelitian ini yaitu seluruh karyawan pada PDAM Kota Palopo dan masyarakat kelurahan murante kecamatan 
mungkajang Kota Palopo. Berdasarkan data yang ada, jumlah karyawan PDAM Kota Palopo berjumlah 199 orang, sehingga populasi dalam penelitian ini berjumlah 199 orang dan jumlah masyarakat kelurahan murante 4.466 jiwa. Sampel digunakan jika populasi yang akan diteliti itu dalam jumlah yang besar, maka untuk menghemat tenaga, waktu dan dana diberlakukanlah sampel. Untuk itu sampel yang diambil dari populasi tersebut harus betulbetul mewakili.

\section{Teknik pengumpulan data}

Metode pengumpulan data yang akan dilakukan dalam penelitian ini berupa:

1. Wawancara

2. Observasi

3. Dokumentasi

4. Trianggulasi

5. Kuesioner

\section{E. Teknik analisis data}

Analisis data merupakan faktor penting dalam suatu penelitian. Analisis adalah suatu proses menghubungkan, memisahkan, dan mengelompokkan antara fakta yang satu dengan fakta yang lain sehingga dapat ditarik suatu kesimpulan sebagai akhir pembahasan. Selain itu, analisis data merupakan proses pencandraan (description) dan penyusunan transkip interviu secara material lain yang telah terkumpul.

Untuk itu, Penelitian ini merupakan penelitian dengan metode kombinasi desain Concurrent Trianggulation (Campuran Kuantitatif dan Kualitatif secara seimbang) dengan penggunaan secara bersama-sama, dalam waktu yang sama, tetapi independen untuk menjawab masalah yang sejenis. sehingga dalam analisis data menggunakan teknik analisis secara kualitatif dan kuantitatif. ${ }^{21}$ Dalam analisis data kualitatif bersifat induktif, yaitu suatu analisis berdasarkan data yang diperoleh, selanjutnya dikembangkan menjadi hipotesis. ${ }^{22}$ Kemudian dalam dalam analisis data Kuantitatif menggunakan statistik yaitu statistik deskriptif, dan statistik inferensial/induktif. Statistik inferensial meliputi statistic parametris dan statistic nonparametris. ${ }^{23}$

Penelitian ini termasuk penelitian untuk pengembangan ilmu dengan bersifat Komparatif, data yang diperoleh dari wawancara, observasi dan studi dokumentasi (data kualitatif), dan data yang diperoleh dari kuesioner (data kuantitatif) selanjutnya diananlisis dengan cara 
dibandingkan, sehingga dapat diperoleh data lebih luas, lengkap, mendalam dan pasti, ${ }^{24}$ serta dapat dibuat kesimpulan apakah kedua data tersebut (kualitatif dan kuantitatif) saling memperkuat, memperlemah atau bertentangan.

1. Pengujian Validitas

2. Pengujian Reliabilitas

3. Distribusi Frekuensi

4. Pengujian Analisis Rank Spearman dan Kendall Tau

\section{HASIL DAN PEMBAHASAN PENELITIAN}

\section{A. Gambaran mengenai pra dan pasca implementasi GCG di PDAM Kota Palopo.}

1. Uji Validitas dan Reliabilitas

Untuk melihat validitas setiap pertanyaan dari pra dan pasca implementasi prinsip-prinsip GCG, dapat dilihat pada kolom Corrected Item-Total Correlation.

a. Sebelum penerapan GCG (Periode tahun 2010-2012)
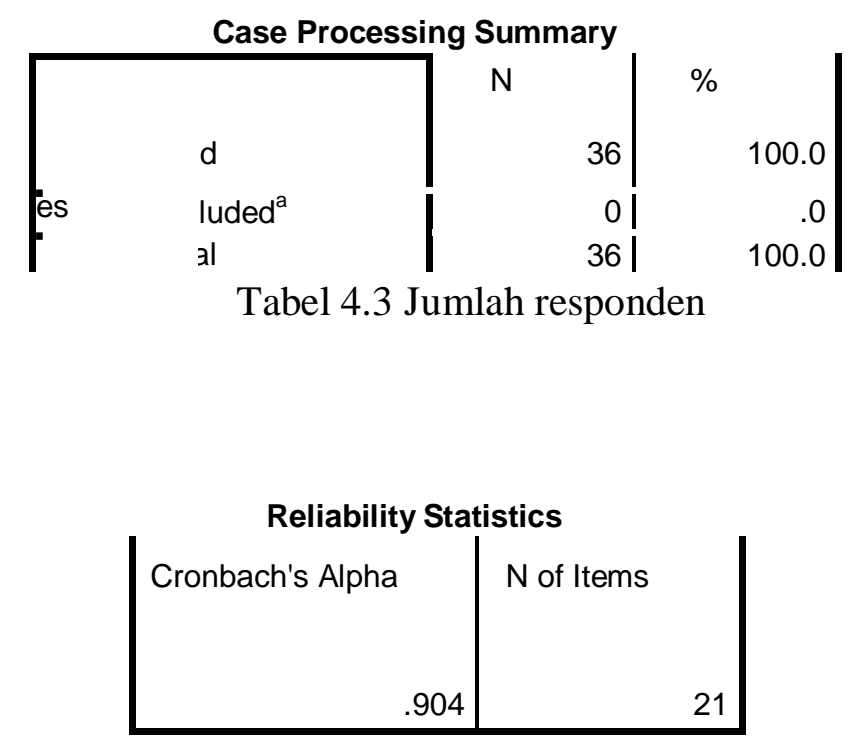

Tabel 4.4 Tingkat reliabilitas pertanyaan 


\begin{tabular}{|c|c|c|c|c|}
\hline & $\begin{array}{c}\text { ale Mean if } \\
\text { Item } \\
\text { Deleted } \\
79.2778\end{array}$ & $\begin{array}{c}\text { le Variance } \\
\text { if Item } \\
\text { Deleted } \\
100.721\end{array}$ & $\begin{array}{c}\text { rected Item- } \\
\text { Total } \\
\text { Correlation } \\
.575\end{array}$ & $\begin{array}{c}\text { ronbach's } \\
\text { Alpha if Item } \\
\text { Deleted }\end{array}$ \\
\hline Pertanyaan 1 (Transparansi) & 79.2500 & 100.879 & .543 & .899 \\
Pertanyaan 2 (Transparansi) & 79.2500 & 100.421 & .576 & .899 \\
Pertanyaan 3 (Transparansi) & 79.3611 & 100.180 & .474 & .901 \\
Pertanyaan 4 (Transparansi) & 79.1667 & 99.800 & .634 & .898 \\
Pertanyaan 5 (Transparansi) & 79.3611 & 100.180 & .474 & .901 \\
\hline Pertanyaan 6 (Akuntabilitas) & 79.0556 & 101.025 & .445 & .902 \\
Pertanyaan 7 (Akuntabilitas) & 79.1944 & 102.218 & .511 & .901 \\
Pertanyan 8 (Akuntabilitas) & 79.4444 & 100.140 & .372 & .905 \\
Pertanyaan 9 (Akuntabilitas) & 79.4722 & 95.742 & .584 & .899 \\
Pertanyaan 10 (Akuntabilitas) & 79.1111 & 100.330 & .507 & .900 \\
\hline ertanyaan 11 (Pertanggungjawaban) & 78.9167 & 100.764 & .520 & .900 \\
ertanyaan 12 (Pertanggungjawaban) & 78.909 \\
ertanyaan 13 (Pertanggungjawaban) & 79.0833 & 101.964 & .580 & .900 \\
ertanyaan 14 (Pertanggungjawaban) & 79.1667 & 96.943 & .690 & .896 \\
\hline Pertanyaan 15 (Kemandirian) & 79.0556 & 96.797 & .584 & .898 \\
Pertanyaan 16 (Kemandirian) & 79.1389 & 99.552 & .542 & .900 \\
\hline Pertanyaan 17 (Kemandirian) & 79.2500 & 98.764 & .442 & .903 \\
Pertanyaan 18 (Kemandirian) & 79.3056 & 97.190 & .643 & .897 \\
\hline Pertanyaan 19 (Kewajaran) & 79.1667 & 96.943 & .690 & .896 \\
Pertanyaan 20 (Kewajaran) & 79.3889 & 102.473 & .413 & .903 \\
Pertanyaan 21 (Kewajaran) & 78.9167 & 100.764 & .520 & .900 \\
\hline
\end{tabular}

Tabel 4.5 Tingkat validitas pertanyaan responden

Dari hasil tabel Item-Total Statistics, semua item pertanyaan mempunyai nilai Corrected Item-Total Correlation lebih besar dari $\mathrm{r}$ tabel $(0,361)$ sehingga semua item pertanyaan tersebut dikatakan valid dengan nilai reliabilitas 0,904 .

b. Sesudah penerapan GCG (Periode tahun 2012-2014)

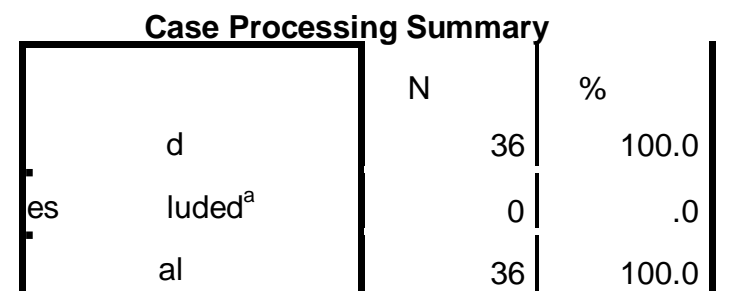

Tabel 4.6 Jumlah responden

Reliability Statistics

\begin{tabular}{|r|r|}
\hline onbach's Alpha & N of Items \\
\hline .960 & 21 \\
\hline
\end{tabular}

Tabel 4.7 Tingkat reliabilitas pertanyaan 


\begin{tabular}{|c|c|c|c|c|}
\hline & $\begin{array}{l}\text { cale Mean if } \\
\text { Item Deleted }\end{array}$ & $\begin{array}{l}\text { ale Variance if } \\
\text { Item Deleted }\end{array}$ & $\begin{array}{c}\text { rected Item-Total } \\
\text { Correlation }\end{array}$ & $\begin{array}{l}\text { ronbach's } \\
\text { Alpha if Item } \\
\text { Deleted }\end{array}$ \\
\hline tanyaan 1 (Transparansi) & 87.8889 & 114.102 & .846 & .957 \\
\hline tanyaan 2 (Transparansi) & 88.2222 & 118.578 & .451 & .961 \\
\hline anyaan 3 (Transparansi) & 87.8611 & 115.209 & .713 & .958 \\
\hline anyaan 4 (Transparansi) & 88.0833 & 114.821 & .684 & .959 \\
\hline tanyaan 5 (Transparansi) & 87.8889 & 114.102 & .846 & .957 \\
\hline tanyaan 6 (Akuntabilitas) & 87.9722 & 112.656 & .847 & .957 \\
\hline tanyaan 7 (Akuntabilitas) & 88.0833 & 115.621 & .670 & .959 \\
\hline tanyan 8 (Akuntabilitas) & 88.0278 & 117.799 & .512 & .961 \\
\hline tanyaan 9 (Akuntabilitas) & 88.0278 & 114.028 & .765 & .958 \\
\hline tanyaan 10 (Akuntabilitas) & 88.1667 & 114.314 & .705 & .958 \\
\hline $\begin{array}{l}\text { anyaan } 11 \\
\text { (Pertanggungjawaban) }\end{array}$ & 87.8889 & 114.102 & .846 & .957 \\
\hline $\begin{array}{l}\text { tanyaan } 12 \\
\text { (Pertanggungjawaban) }\end{array}$ & 88.1667 & 113.343 & .813 & .957 \\
\hline $\begin{array}{l}\text { tanyaan } 13 \\
\text { (Pertanggungjawaban) }\end{array}$ & 87.9167 & 112.536 & .805 & .957 \\
\hline $\begin{array}{l}\text { tanyaan } 14 \\
\text { (Pertanggungjawaban) }\end{array}$ & 87.8889 & 114.102 & .846 & .957 \\
\hline tanyaan 15 (Kemandirian) & 88.0278 & 113.228 & .819 & .957 \\
\hline tanyaan 16 (Kemandirian) & 87.9167 & 112.536 & .805 & .957 \\
\hline tanyaan 17 (Kemandirian) & 88.0278 & 118.713 & .452 & .961 \\
\hline anyaan 18 (Kemandirian) & 87.8889 & 114.730 & .702 & .958 \\
\hline tanyaan 19 (Kewajaran) & 88.0556 & 118.225 & .489 & .961 \\
\hline tanyaan 20 (Kewajaran) & 87.9167 & 112.536 & .805 & .957 \\
\hline tanyaan 21 (Kewajaran) & 87.8611 & 116.352 & .679 & .959 \\
\hline
\end{tabular}

Tabel 4.8 Tingkat validitas pertanyaan responden

Dari hasil tabel Item-Total Statistics, semua item pertanyaan mempunyai nilai Corrected Item-Total Correlation lebih besar dari $r$ tabel $(0,361)$ sehingga semua item pertanyaan tersebut dikatakan valid dengan nilai reliabilitas 0,960 . 
2. Distribusi frekuensi

Untuk mengetahui bagaimana gambaran mengenai Penerapan Prinsip GCG di PDAM Kota Palopo, maka penulis menguraikan per indikator terkait prinsip-prinsip GCG.

a. Sebelum penerapan prinsip-prinsip GCG di PDAM Kota palopo (Tahun 2010-2012)

\begin{tabular}{|c|c|c|c|}
\hline NO. & ALTERNATIF JAWABAN & FREKUENSI & $\%$ \\
\hline 1 & SANGAT BAIK & 201 & 26,59 \\
\hline 2 & BAIK & 376 & 49,74 \\
\hline 3 & $\begin{array}{c}\text { NORMAL/TIDAK ADA } \\
\text { PERUBAHAN }\end{array}$ & 134 & 17,73 \\
\hline 4 & BURUK & 38 & 5,02 \\
\hline 5 & SANGAT BURUK & 7 & 0,92 \\
\hline & JUMLAH & 756 & 100 \\
\hline
\end{tabular}

Tabel 4.32 Kriteria nilai terhadap pra implementasi Good Corporate Governance di PDAM

Kota Palopo

Maka dapat di simpulkan bahwa sebelum penerapan Good Corporate Governance di PDAM Kota Palopo yaitu tahun 2010 sampai 2012 adalah tergolong baik dengan jumlah $49.74 \%$. Berdasarkan data diatas penulis menyimpulkan bahwa PDAM kota palopo sebelum diterapkannya Good Corporate Governance yaitu di tahun 2012 oleh regulasi pemerintah daerah, perusahan daerah tersebut jauh sudah menerapkannya karena perusahaan daerah tersebut hanya berlandaskan prinsip perusahaan yang sehat sehingga bagian dari indikator GCG sudah ada yang diterapkan yaitu terkait dengan administrasi dan tanggungjawab sosial, akan tetapi penerapannya belum sepenuhnya berjalan.

b. Sesudah penerapan prinsip-prinsip GCG di PDAM Kota Palopo (Tahun 2012-2014).

\begin{tabular}{|r|c|c|c|}
\hline NO. & ALTERNATIF JAWABAN & FREKUENSI & $\mathbf{\%}$ \\
\hline 1 & SANGAT BAIK & 405 & 53,57 \\
\hline 2 & BAIK & 376 & 32,81 \\
\hline 3 & NORMAL/TIDAK ADA & 134 & 13,62 \\
\hline 4 & PERUBAHAN & 0 & 0 \\
\hline 5 & SANGAT BURUK & 0 & 0 \\
\hline
\end{tabular}

Tabel 4.55 Kriteria nilai terhadap pasca implementasi Good Corporate Governance di PDAM Kota Palopo 
Maka dapat di simpulkan bahwa sesudah penerapan Good Corporate Governance di PDAM Kota Palopo yaitu tahun 2012 sampai 2014 adalah tergolong sangat baik dengan jumlah $53.57 \%$. Berdasarkan data diatas penulis menyimpulkan bahwa PDAM kota palopo sesudah diterapkannya Good Corporate Governance yaitu di tahun 2012, kondisi perusahaan daerah tersebut sudah sangat baik disebabkan keseluruhan prinsip-prinsip GCG diterapkan dan berdampak langsung pada administrasi perusahaan, seperti halnya pada pencatatan dan mengagendakan setiap rapat pada divisi masing-masing bidang serta kualitas SDM yang dimiliki perusahan semakin baik.

\section{B. Persepsi masyarakat sekitar terhadap PDAM Kota Palopo}

1. Uji Validitas dan Reliabilitas

Untuk melihat validitas setiap pertanyaan dari persepsi masyarakat sekitar terhadap PDAM Kota Palopo dapat dilihat pada kolom Corrected Item-Total Correlation.
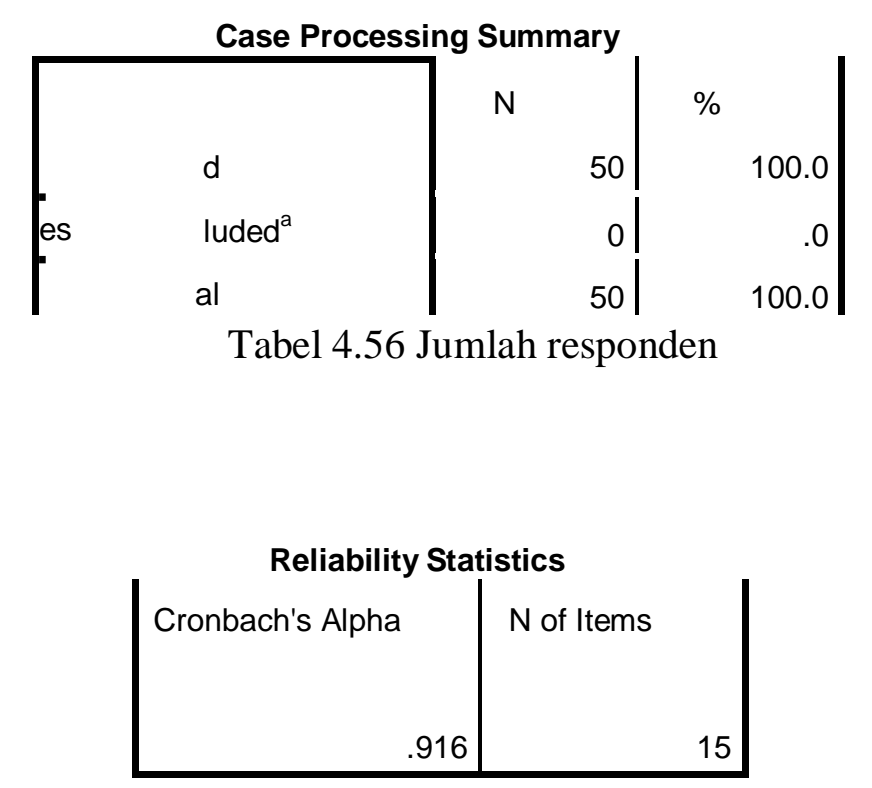

Tabel 4.57 Tingkat reliabilitas pertanyaan 


\begin{tabular}{|c|c|c|c|c|}
\hline \multicolumn{5}{|c|}{ Item-Total Statistics } \\
\hline & $\begin{array}{l}\text { Ale Mean if Item } \\
\text { Deleted }\end{array}$ & $\begin{array}{l}\text { ale Variance if } \\
\text { Item Deleted }\end{array}$ & $\begin{array}{c}\text { orrected Item- } \\
\text { Total } \\
\text { Correlation }\end{array}$ & $\begin{array}{l}\text { nbach's Alpha if } \\
\text { Item Deleted }\end{array}$ \\
\hline $\begin{array}{c}\text { Pertanyaan } 1 \text { (Proses } \\
\text { Produksi) }\end{array}$ & 57.5000 & 36.255 & .466 & .915 \\
\hline $\begin{array}{c}\text { Pertanyaan } 2 \text { (Proses } \\
\text { Produksi) }\end{array}$ & 57.5400 & 35.315 & .622 & .911 \\
\hline $\begin{array}{c}\text { Pertanyaan } 3 \text { (Proses } \\
\text { Produksi) }\end{array}$ & 57.9000 & 35.888 & .666 & .911 \\
\hline $\begin{array}{l}\text { Pertanyaan } 4 \text { (Dampak } \\
\text { Keberadaan PDAM) }\end{array}$ & 58.0000 & 32.367 & .729 & .907 \\
\hline $\begin{array}{l}\text { Pertanyaan } 5 \text { (Dampak } \\
\text { Keberadaan PDAM) }\end{array}$ & 58.5000 & 34.949 & .698 & .909 \\
\hline $\begin{array}{r}\text { Pertanyaan } 6 \text { (Dampak } \\
\text { Keberadaan PDAM) }\end{array}$ & 58.4600 & 33.233 & .542 & .916 \\
\hline $\begin{array}{r}\text { Pertanyaan } 7 \text { (Dampak } \\
\text { Keberadaan PDAM) }\end{array}$ & 58.3600 & 33.500 & .511 & .917 \\
\hline $\begin{array}{l}\text { Pertanyaan } 8 \text { (Dampak } \\
\text { Keberadaan PDAM) }\end{array}$ & 57.7000 & 35.153 & .661 & .910 \\
\hline $\begin{array}{l}\text { Pertanyaan } 9 \text { (Dampak } \\
\text { Keberadaan PDAM) }\end{array}$ & 58.5000 & 34.949 & .698 & .909 \\
\hline $\begin{array}{r}\text { Pertanyaan } 10 \text { (Dampak } \\
\text { Keberadaan PDAM) }\end{array}$ & 58.1000 & 32.051 & .942 & .899 \\
\hline $\begin{array}{c}\text { ertanyaan } 11 \text { (Kepuasan } \\
\text { Pelanggan PDAM) }\end{array}$ & 57.7000 & 36.459 & .430 & .916 \\
\hline $\begin{array}{c}\text { ertanyaan } 12 \text { (Kepuasan } \\
\text { Pelanggan PDAM) }\end{array}$ & 57.9000 & 31.398 & .862 & .901 \\
\hline $\begin{array}{c}\text { ertanyaan } 13 \text { (Kepuasan } \\
\text { Pelanggan PDAM) }\end{array}$ & 58.0400 & 32.039 & .799 & .904 \\
\hline $\begin{array}{c}\text { ertanyaan } 14 \text { (Kepuasan } \\
\text { Pelanggan PDAM) }\end{array}$ & 57.5000 & 36.255 & .466 & .915 \\
\hline $\begin{array}{c}\text { ertanyaan } 15 \text { (Kepuasan } \\
\text { Pelanggan PDAM) }\end{array}$ & 57.7000 & 36.459 & .430 & .916 \\
\hline
\end{tabular}

Tabel 4.58 Tingkat validitas pertanyaan responden

Dari hasil tabel Item-Total Statistics, semua item pertanyaan mempunyai nilai Corrected Item-Total Correlation lebih besar dari $r$ tabel $(0,361)$ sehingga semua item pertanyaan tersebut dikatakan valid dengan nilai reliabilitas 0,916. 
2. Distribusi Frekuensi

Untuk mengetahui persepsi masyarakat sekitar terhadap PDAM kota palopo, penulis mengumpulkan tiap-tiap jawaban kedalam poin, untuk jawaban SB poinnya 5, jawaban B poinnya 4, jawaban $\mathrm{N}$ poinnya 3, jawaban Br poinnya 2 dan jawaban $\mathrm{SBr}$ poinnya 1 , dari jawaban angket di atas maka terkumpul ke dalam tabel berikut :

\begin{tabular}{|r|c|c|}
\hline \multicolumn{1}{l|}{ No. } & Nilai & Jumlah Rekapan \\
\hline 1 & SB & 238 \\
\hline 2 & $\mathrm{~B}$ & 377 \\
\hline 3 & $\mathrm{~N}$ & 130 \\
\hline 5 & $\mathrm{Br}$ & 5 \\
\hline & $\mathrm{SBr}$ & 0 \\
\hline
\end{tabular}

Tabel 4.75 Jumlah rekapan nilai keseluruhan indicator terhadap jawaban responden

Dalam menganalisis data rekapan menggunakan rumus presentase untuk mengetahui baik dan buruknya persepsi masyarakat sekitar terhadap PDAM Kota Palopo :

$$
\mathrm{P}=\frac{\mathrm{F}}{\mathrm{N}} \times 100 \%
$$

\begin{tabular}{|r|c|c|c|}
\hline NO. & ALTERNATIF JAWABAN & FREKUENSI & $\mathbf{\%}$ \\
\hline 1 & SANGAT BAIK & 238 & 31,73 \\
\hline 2 & BAIK & 377 & 50,27 \\
\hline 3 & CUKUP BAIK & 130 & 17,33 \\
\hline 5 & BURUK & 5 & 0,67 \\
\hline 5 & SANGAT BURUK & 0 & 0 \\
\hline
\end{tabular}

Tabel 4.76 Kriteria nilai persepsi masyarakat sekitar terhadap PDAM Kota Palopo

Maka dapat di simpulkan bahwa persepsi masyarakat terhadap PDAM Kota Palopo adalah tergolong baik dengan jumlah 50,27 \%. Berdasarkan data diatas penulis menyimpulkan bahwa masyarakat selama ini memiliki persepsi yang baik terhadap PDAM 
dikarenakan proses produksi, dampak keberadaan PDAM (sosial, ekonomi, lingkungan hidup) dan kepuasan pelanggan terhadap pelayanan PDAM selama ini dapat dikategorikan baik, akan tetapi yang menjadi fokus PDAM terhadap masyarakat adalah sangatlah perlu meningkatkan perekonomian masyarakat sekitar, karena dilingkungan masyarakat masih kurang pemberdayaan usaha kecil menengah, sehingga PDAM diharapkan mampu meningkatkan pemberdayaan masyarakat, baik itu berupa bantuan dana pengembangan usaha kreatif masyarakat atau mengadakan kegiatan Usaha Kecil Menengah (UKM) untuk memberdayakan masyarakat sekitar serta bantuan sosial bagi masyarakat yang tidak mampu atau pembuatan WC umum dan bantuan air hibah.

\section{Kinerja keuangan PDAM Kota Palopo}

Untuk mengetahui bagaimana gambaran mengenai kinerja keuangan di PDAM Kota Palopo, maka penulis menyajikan dalam bentuk tabel sebagai berikut:

\begin{tabular}{|c|c|c|c|}
\hline TAHUN & NPM & ROA & ROE \\
\hline 2010 & $10,77 \%$ & $8,70 \%$ & $34,82 \%$ \\
\hline 2011 & $6,50 \%$ & $5,24 \%$ & $12,10 \%$ \\
\hline 2012 & $8,82 \%$ & $5,52 \%$ & $8,94 \%$ \\
\hline 2013 & $3,38 \%$ & $17,91 \%$ & $2,51 \%$ \\
\hline 2014 & $3,46 \%$ & $1,76 \%$ & $2,31 \%$ \\
\hline
\end{tabular}

Tabel 4.77 Laporan keuangan PDAM Kota Palopo dengan perhitungan Rasio Profitabilitas (Periode tahun 2010-2014)

Dari data tabel diatas dapat diketahui bahwa terjadi penurunan yang sangat signifikan setiap tahunnya mengenai kinerja keuangan terkait dengan perhitungan rasio profitabilitas, dalam penjelasan ini perusahaan dalam memperoleh laba dan efisiensi perusahaan dalam menggunakan aktiva atau modal yang dimiliki sangat rendah, terlihat dari Net profit margin (NPM) ditahun 2010 sangat tinggi disebabkan laba di perusahaan tersebut lebih besar dari pada pendapatan usaha dan terjadi penurunan sangat signifikan sampai ditahun 2014 disebabkan laba yang diperoleh perusahaan sangat kecil dibandingkan dengan pendapatan usaha. Begitu pula Return on equity atau tingkat efisiensi perusahaan dalam mengelola equitynya untuk menghasilkan laba bersih perusahaan yang terjadi penurunan setiap tahunya disebabkan persentase laba bersih perusahaan sangat kecil sedangkan equitas (Modal pemerintah dan modal PDAM) lebih besar. Lain hal Return on assets atau kemampuan perusahaan memperoleh laba dengan memanfaatkan aktiva yang dimiliki yang memiliki 
kenaikan signifikan dari tahun 2010 ke tahun 2013 disebabkan diaktifkannya mega proyek bambalu sehingga ditahun 2013 terjadi kenaikan sebesar 17,91\%. Kinerja keuangan di PDAM Kota Palopo dari tahun 2010 sampai 2014 terjadi penurunan sehingga tingkat keberhasilan PDAM dari aspek keuangan memiliki nilai 45 (Kurang). Hubungan implementasi Good Corporate Governance terhadap kinerja keuangan tidak sejalan dengan kenaikan dari penerapan prinsip-prinsip GCG tersebut, dikarenakan permasalahanpermasalahan yang dihadapi perusahaan. Penerapan prinsip-prinsip GCG di PDAM Kota Palopo memiliki peranan dari segi penguatan administrasi, sehingga dampak terhadap kinerja keuangan dari segi profitabilitas hanya sedikit. Berdasarkan data yang di peroleh hanya Return on Asset yang memiliki kenaikan sejalan dengan penerapan prinsip-prinsip GCG tetapi hanya berlangsung 2 tahun dari sesudah penerapan prinsip-prinsip GCG dan kembali mengalami penurunan di tahun selanjutnya.

\section{PENUTUP}

\section{A. Kesimpulan}

Berdasarkan rumusan masalah dan hasil penelitian dapat diambil kesimpulan sebagai berikut:

Berdasarkan pembahasan dan analisa pada bab-bab sebelumnya maka peneliti akan membuat kesimpulan dari penelitian yang berjudul Analisis pra dan pasca implementasi prinsip-prinsip Good Corporate Governance (GCG) terhadap persepsi masyarakat dan kinerja keuangan pada Perusahaan Daerah Air Minum (PDAM) Kota Palopo sebagai berikut:

1. Kondisi PDAM tahun 2010 sampai 2012 Kota palopo sebelum implementasi prinsipprinsip Good Corporate Governance berjalan dengan baik disebabkan hampir keseluruhan prinsip-prinsip GCG diterapkan di perusahaan tersebut meskipun belum ada regulasi dari pemerintah daerah yang mengatur tentang GCG tetapi dengan berlandaskan prinsip perusahaan yang sehat sehingga bagian dari indikator GCG sudah ada yang diterapkan terkait dengan administrasi dan tanggungjawab sosial. Sedangkan pada tahun 2012 sampai 2014 setelah implementasi prinsip-prinsip Good Corporate Governance, kondisi PDAM sudah sangat baik disebabkan keseluruhan prinsip-prinsip GCG diterapkan dan berdampak langsung pada administrasi perusahaan, seperti halnya pada pencatatan dan mengagendakan setiap rapat pada divisi masing-masing bidang serta kualitas SDM yang dimiliki perusahan semakin baik.

2. Persepsi masyarakat terhadap PDAM Kota Palopo adalah tergolong baik dengan jumlah $50,27 \%$. Berdasarkan data tersebut penulis menyimpulkan bahwa masyarakat selama ini 
memiliki persepsi yang baik terhadap PDAM dikarenakan proses produksi, dampak keberadaan PDAM (sosial, ekonomi, lingkungan hidup) dan kepuasan pelanggan terhadap pelayanan PDAM selama ini dijalankan dengan baik. Persepsi masyarakat terhadap penerapan GCG di PDAM sudah sejalan dengan apa yang menjadi prinsip dari Good Corporate Governance dikarenakan penerapan GCG di perusahaan selama ini berdampak terhadap masyarakat dan dapat dirasakan langsung kepada masyarakat.

3. Kinerja Keuangan di PDAM Kota palopo dari tahun 2010-2014 mengalami penurunan yang signifikan dari segi profitabilitas dan dapat dikatakan kinerja keuangan di PDAM yang kurang, dimana indikator NPM ditahun 2010 sebesar 10,77\% sedangkan ditahun 2014 sebesar 3,46\%, penyebab adalah biaya bahan baku, over head, serta biaya tenaga kerja yang sangat tinggi sehingga pendapatan lebih besar daripada laba yang diperoleh perusahaan. Begitu pula dengan indicator ROE yang memiliki penurunan yang sangat signifikan, dimana persentase di tahun 2010 sebesar 34,82\% sedangkan di tahun 2012 hanya sebesar $2,31 \%$ disebabkan laba yang diperoleh perusahaan sangat kecil dibandingkan ekuitas perusahaan. Lain halnya dengan indikator ROA yang memiliki peningkatan di tahun 2013 sebesar 17,91\% disebabkan pengaktifan mega proyek bambalu sehingga keuntungan yang diperoleh dari pengelolaan asset sangat tinggi karena ROA akan tinggi jika diperusahaan tersebut terdapat proyek yang dapat mendatangkan laba perusahaan.

4. Dari segi penerapan GCG terdapat hubungan yang positif rendah pada sebelum penerapan prinsip-prinsip GCG hingga sesudah penerapan GCG dalam hal pengelolaan baik dari segi administrasi perusahaan maupun program-program yang direncanakan perusahaan, tetapi dalam lingkup kinerja keuangan kenaikan dari penererapan GCG tidak sejalan dengan Kinerja keuangan yang mengalami penurunan dari sebelum penerapan GCG hingga sesudah penerapan GCG, hanya indikator ROA yang baik sehingga memiliki kenaikan dibandingkan sebelum penerapan GCG. Hal ini dapat disimpulkan bahwa penerapan GCG hanya memperkuat di bagian administrasi perusahaan dan tidak memiliki hubungan yang kuat terhadap kinerja keuangan PDAM Kota Palopo.

\section{B. Saran}

Berdasarkan penelitian yang telah dilakukan maka peneliti dapat memberikan saran kepada pihak terkait yaitu Perusahaan Daerah Air Minum (PDAM) Kota Palopo dalam hal ini adalah sebagai berikut: 
1. PDAM perlu meningkatkan perekonomian masyarakat sekitar, karena dilingkungan masyarakat masih kurang pemberdayaan usaha kecil menengah, sehingga PDAM diharapkan mampu meningkatkan pemberdayaan masyarakat, baik itu berupa bantuan dana pengembangan usaha kreatif masyarakat atau mengadakan kegiatan Usaha Kecil Menengah (UKM) untuk memberdayakan masyarakat sekitar serta bantuan sosial bagi masyarakat yang tidak mampu atau pembuatan WC umum dan bantuan air hibah perlu ditingkatkan lagi.

2. Peningkatan pelayanan terhadap pelanggan perlu ditingkatkan lagi dikarenakan masih terdapat beberapa permasalahan yang dihadapi pelanggan PDAM yaitu tidak sesuainya pembayaran air dengan pemakaian air terhadap pelanggan serta informasi yang masih terkadang pelanggan masih belum mengetahui apabila tiba-tiba ada perubahan atau biayabiaya tambahan terkait dengan pembayaran rekening air, sehingga nantinya kepercayaan pelanggan terhadap PDAM tetap terjaga dengan baik.

3. Mengingat kinerja keuangan PDAM yang setiap tahunnya mengalami penurunan, oleh karena itu perusahaan harus memiliki trobosan, strategi, serta perencanaan bisnis yang dapat memperoleh keuntungan dalam untuk menenekan persentase angka kinerja keuangan yang semakin menurun serta dapat menutupi permasalahan-permasalahan yang dihadapi perusahaan dibidang keuangan.

4. Perusahaan harus tetap memperhatikan kualitas SDM yang dimiliki sehingga pengelolaan perusahaan tetap berjalan dan berkembang dengan baik dalam menghadapai tekanan dimasa mendatang.

\section{DAFTAR PUSTAKA}

Adi Nugroho, Faisal, Analisis pengaruh Corporate Social Responbility dan karakteristik Good Corporate Governance tehadap kinerja Perusahaan (Studi empiris pada perusahaan manufaktur di BEI tahun 2012), Skripsi, Universitas diponegoro Semarang, 2014.

Anton, Analisis Good Corporate Governance Terhadap Kinerja Keuangan Perusahaan, Universitas AKI, vol 3. nomor 1, 2012.

Aplikasi Kamus Besar Bahasa Indonesia, http://www.yufid.org

Ariani Dian, Persepsi masyarakat umum terhadap Bank Syariah di Medan, Tesis, Universitas Sumatera Utara, 2007. 
Ayu Lestari, Tiara, Pengaruh Efektivitas Pengendalian Intern Terhadap Penerapan PrinsipPrinsip Good Corporate Governance, Jurnal Akutansi, Universitas Komputer Indonesia, 2014.

Departemen Agama RI, Al-Hikmah Al-Qur'an Dan Terjemahnnya, Bandung: Diponegoro, 2015.

Efendi, Muh. Arief, The power of Good Corporate Governance: Teori dan implementasi, Jakarta: Salemba Empat, 2009.

Fajaruddin, Ahmad, Implementasi GCG dalam Perspektif Islam (Studi Kasus di RS. 'Aisyiyah Bojonegoro), Jurnal Hukum dan Ekonomi Islam, Institut Studi Islam Darussalam Gontor, 2014.

Harian Medan Bisnis,"Good and Clean Governance," 03 Juni 2015. http://mdn.biz.id/n/167128/ (24 Agustus 2016)

Kaihatu, Thomas S., Good Corporate Governance dan Penerapannya di Indonesia, Jurnal Manajemen dan Kewirausahaan, Universitas Kristen Petra Surabaya. vol 8. nomor 1, 2006.

Kementerian BUMN, Peraturan Menteri Negara Badan Usaha Milik Negara tentang Penerapan Tata Kelola Perusahaan yang Baik (Good Corporate Governance), nomor. PER-01/MB/2011.

Kementerian Dalam Negeri, Keputusan Menteri Dalam Negeri tentang Pedoman Kinerja Perusahaan Daerah Air Minum, Nomor 47 Tahun 1999.

Komite Nasional Kebijakan Governance, Pedoman Umum Good Corporate Governance Indonesia, https://www.knkg-indonesia.com 2015.

Monisa Wati, Like, Pengaruh Praktek Good Corporate Governance Terhadap Kinerja Keuangan Perusahaan di Bursa Efek Indonesia, Jurnal Manajemen, Universitas Negeri Padang. vol 1. nomor 1, 2012.

Nazir, Moh., Metode Penelitian, Bogor: Ghalia Indonesia, 2005.

Nuryanto, Yahya "Dasar Kinerja Keuangan," Blog Yahya Nuryanto. http://yanurto.blogspot.co.id/2010/12/dasar-kinerja-keuangan.html, 2015.

Okkyrianto, Rico, Pengaruh Good Corporate Governance terhadap kinerja keuangan perusahaan, Jurnal Ekonomi dan Bisnis, Universitas Brawijaya Malang. vol 2. Nomor 2, 2014.

Pedoman Penulisan Karya Tulis Ilmiah (Makalah, Skripsi, dan Tesis), STAIN Palopo, 2012.

Purwana Harahap, Rinto, Analisis hukum penerapan Tata kelola Perusahaan Yang Baik (Good Corporate Governance) pada Badan Usaha Milik Daerah (studi pada PT. Perkebunan Sumatera Utara), Skripsi, Universitas Sumatera Utara, 2011. 
Puspitawati, Lilis, Implementasi Undang-Undang Keterbukaan Informasi, Corporate Social Responbility (CSR), dan Peran Satuan Pengawas Internal (SPI) dalam mewujudkan praktik Good Corporate Governance pada Badan Usaha Milik Negara (BUMN), Majalah Ilmiah UNIKOM, Universitas Komputer Indonesia Bandung.

Rumapea, Dormatio "Return On Asset (ROA)," Blog Dormatio Rumapea. http://bilongtuyu.blogspot.co.id/2013/05/return-on-assets-roa.html 2015.

Sarayulus Nuh, Iqbal, Penerapan prinsip Good Corporate Governance dalam aspek keterbukaan di BNI syariah cabang Semarang, Skripsi, IAIN Walisongo Semarang, 2012.

Sari, Yessi Amanda, Pengaruh Penerapan Good Corporate Governance Terhadap Informasi Kinerja Keuangan (Studi kasus pada PDAM Tirta Jati Kabupaten Cirebon, PDAM Tirta Dharma Kota Cirebon, PDAM Tirta Medal Kabupaten Sumedang, dan PDAM Tirta Kamuning Kabupaten Kuningan), Skripsi, Universitas Widyatama Bandung, 2014.

Sugiyono, Metode Penelitian Kombinasi, Bandung: Alfabeta,CV, 2013.

Republik Indonesia, Undang-Undang Nomor 5 Tahun 1962 tentang Perusahaan Daerah, Bab I, pasal 2.

Republik Indonesia, Undang-Undang Nomor 5 Tahun 1962 tentang Perusahaan Daerah, Bab II, pasal 5, ayat 1-4.

Wanodyatama, Nungky, "Menjadi BUMN ber-Good Corporate Governance terbaik”.http://bumn.go.id/jasatirta1/berita/687/Menjadi.BUMN.BerGood.Corporate.Governance, 2015.

Zainul Hal, "Good Corporate Governance (GCG)," Official Website of Zainul Hal. http://www.mymirrorlife.net 2015. 